\title{
Comparing the reactivity of different natural clays under thermal and
}

\section{alkali activation}

\author{
Ahmed Zohair Khalifa ${ }^{a^{*}}$,Yiannis Pontikes ${ }^{b}$, Jan Elsen ${ }^{c}$, Özlem Cizer ${ }^{a}$ \\ ${ }^{a}$ KU Leuven, Department of Civil Engineering, Kasteelpark Arenberg 40, 3001 Leuven, Belgium \\ ${ }^{\mathrm{b}} \mathrm{KU}$ Leuven, Department of Materials Engineering, Kasteelpark Arenberg 44, 3001 Leuven, Belgium \\ ${ }^{\mathrm{C}} \mathrm{KU}$ Leuven, Department of Earth and Environmental Sciences, Celestijnenlaan 200C, B-3001 Heverlee, Belgium
}

Received: 19 February 2019 / Accepted: 17 October 2019 / Published online: 05 November 2019

(C) The Author(s) 2019. This article is published with open access and licensed under a Creative Commons Attribution 4.0 International License.

\begin{abstract}
Metakaolin is one of the most popular solid aluminosilicate precursors for the synthesis of geopolymers. Despite its high reactivity and availability, there is a noticeable move towards the use of other natural clays as alternative precursors, due to their plentiful supply and widespread availability. Natural clays usually consist of a combination of 1:1 and 2:1 layer silicates reactivity of which vary. In this work, four different natural clays (SS, BS, MS and WS) composed of 1:1 and 2:1 clay minerals at different proportions were studied for the synthesis of geopolymers. To increase their reactivity prior to alkali activation, the clays were calcined in a laboratory oven at different temperatures $\left(700,750,800,850,900{ }^{\circ} \mathrm{C}\right)$ and different holding times $(10$ seconds to 60 minutes). The reactivity of the calcined clays was assessed by the dissolution test and isothermal conduction calorimetry. $\mathrm{NaOH}$ and a mix of $\mathrm{NaOH}_{\text {and }} \mathrm{Na}{ }_{2} \mathrm{SiO}_{3}$ were used as alkaline activators. The results show that the optimum calcination temperature of $\mathrm{SS}, \mathrm{BS}$ and $\mathrm{MS}$ is $800^{\circ} \mathrm{C}$ with a holding time of 10 minutes. WS is sufficiently calcined at a higher temperature of $900^{\circ} \mathrm{C}$ for 20 minutes. Kaolinite-rich clays (SS) present more reactivity towards alkali activation than clays dominated by smectite or illite.
\end{abstract}

Keywords: Geopolymer; Common clays; Alkali activation; Thermal activation

\section{Introduction}

The search for alternative low carbon and eco-friendly binders to replace cement in some applications is an important subject. One of the promising routes to achieve this is alkali-activated materials. A wide range of reactive aluminosilicate materials can be used for the synthesis of geopolymers. In general, any material having a certain amount of alumina and silica in reactive form and sufficiently soluble in an alkaline solution can be used as a precursor. Natural clays are considered to be the most abundant and widespread aluminosilicate source on earth. Metakaolin, generated by the calcination of kaolinite clay, is a very common natural solid aluminosilicate precursor for the synthesis of geopolymers [1,2] due to their high reactivity and consistent composition. The main drawbacks of metakaolinbased geopolymer for mass-scale application are the high water demand, which results from the high surface area and plate-like shape of metakaolin $[3,4]$ and the limitation of high purity kaolinite deposits that are commercially available. Other individual clay minerals were previously studied as a precursor for the evaluation of the pozzolanic reactivity [5-
12], the development of new supplementary cementitious materials (SCMs) $[13,14]$, as well as for geopolymerization in both uncalcined $[15,16]$ and calcined form [17-19]. Natural common clays usually consist of a combination of different clay minerals (Kaolinite, montmorillonite, illite, halloysite, and others) and non-clay minerals (quartz, calcite, feldspars, mica, anatase) due to specific weathering conditions, which results in a wide range of mineralogical structure and chemical compositions.

The most applied route to increase the reactivity of clays prior to alkali activation is calcination that involves heating the clays to a specific temperature so that the clays undergo dehydration and dehydroxylation. Hence, the transformation of Al coordination from octahedral (Al $\mathrm{IV}^{\mathrm{V}}$ ) to pentahedral (Al $)$ and tetrahedral $\left(\mathrm{Al}^{\mathrm{IV}}\right.$ ) occurs. These transformations depend on the mineralogy, the degree of ordering, the particle size of clay precursor, as well as the amount and type of associated minerals present $[10,11]$.

The present work aims to determine the optimum thermal treatment (Calcination temperature, holding time, and cooling down) for four different types of natural common

* Corresponding author: Ahmed Zohair Khalifa, E-mail: ahmed.khalifa@kuleuven.be 
clays and to study the effect of the mineralogical composition on the reactivity of these clays.

\section{Materials and experimental methods \\ 2.1 Materials}

Four different natural clay types, named SS, BS, WS, and MS were used in this study. These clays were obtained from Sibelco, Belgium. The natural-moist clays were first dried at 60 ${ }^{\circ} \mathrm{C}$ for 2 days and crushed in a jaw mill, then sieved to $500 \mu \mathrm{m}$. Sodium hydroxide $(\mathrm{NaOH})$ of analytical grade was purchased from VWR Chemicals. The $\mathrm{NaOH}$ solutions were prepared by dissolving sodium hydroxide pellets in deionized water. Sodium silicate $\left(\mathrm{Na}_{2} \mathrm{SiO}_{3}\right)$ of reagent grade was purchased from ABCR-GBBH, Germany (39\%-40\% silicates in water). These solutions were used as alkaline activators in the synthesis of geopolymers.

\subsection{Experimental methods}

The natural raw clays were calcined in a laboratory oven up to $700,750,800,850$ and $900{ }^{\circ} \mathrm{C}$ for different holding times ranging from 10 seconds to 60 minutes at each temperature. After calcination, clays were taken out of the oven for cooling to room temperature, to avoid the crystallization of the newly formed amorphous phases. The dissolution test was performed by mixing $0.25 \mathrm{~g}$ of the calcined clay in $20 \mathrm{ml}$ of $6 \mathrm{M}$ $\mathrm{NaOH}$ at a solution/solid mass ratio equal to 80 , which was high enough to avoid the condensation of the aluminosilicate. The suspensions were mixed at room temperature $\left(25^{\circ} \mathrm{C}\right)$ under continuous shaking for 24 hours to promote the leaching of $\mathrm{Si}$ and $\mathrm{Al}$ before filtration and dilution with nitric acid. The solutions that contain dissolved alumina and silica were analyzed by ICP-OES. Isothermal conduction calorimetry (TAM Air Device, TA instruments) was used to study the clay reactivity at different calcination temperatures and time with $\mathrm{NaOH}$ activator at $20{ }^{\circ} \mathrm{C}$ for 5 days. The cumulative heat released by the geopolymerization reactions was recorded and normalized by the mass of the starting materials.

Both raw and selected calcined clays were characterized using quantitative X-ray diffraction (Philips PW 1830 diffractometer) using a scan rate of $2 \mathrm{~s}$ per step and a CuK $\alpha$ radiation step size of $0.02^{\circ} 2 \theta$, and a scan range of 5 to $65^{\circ} 2 \theta$ at $40 \mathrm{kV}$ and $20 \mathrm{~mA}$. The mineralogical identification and quantification of the raw clays were performed with the X-ray viewer and QUANTA full-pattern fitting software (Chevron ETC proprietary). Zincate was used as an internal standard to quantify the mineralogical composition of raw clays. The chemical composition of the clay minerals was determined using An Inductive Coupled Plasma Optical Emission Spectrometer (ICP-OES) (Varian 720Es). The specific surface area of clay minerals was determined using the BrunauerEmmett-Teller (BET) method. The samples were pre-treated by heating to $400{ }^{\circ} \mathrm{C}$ for $12 \mathrm{~h}$ in a continuous $\mathrm{N}_{2}$ gas flow. The measurement was performed on a Micrometrics Tristar 3000 using $\mathrm{N}_{2}$ as an adsorbate. A laser particle size analyzer
(LS 13 320) was used for particle size analysis of raw and calcined clay. The $d_{90}, d_{50}$, and $d_{10}$ diameters were calculated.

Selected calcined clays, which showed a complete dehydroxylation and high dissolution rate of $\mathrm{Si}$ and $\mathrm{Al}$, were used to synthesize geopolymers. $\mathrm{NaOH}$ and a mix of $\mathrm{NaOH}$ and $\mathrm{Na}_{2} \mathrm{SiO}_{3}$ were used as alkaline activators for the synthesis of geopolymers at a solution/binder ratio of 1 . The choice if this ratio is based on experimental trials of lower S/B ratios, but these lower S/B ratios were insufficiently workable for SS and BS. This is due to the fact that the amount of amorphous phases influences the absorption processes and the affinity of the surface to the water, therefore the wettability value of SS and $\mathrm{BS}$ is high [20].

\section{Results and discussion \\ 3.1 Characterization of raw clays}

The bulk chemical composition and the loss on ignition of the raw natural clays are given in Table 1 , in which $\mathrm{SiO}_{2}$ and $\mathrm{Al}_{2} \mathrm{O}_{3}$ were indicated as the main constituents of all clays. The high amounts of alumina in SS compared to the other clays indicates the presence of kaolinite, considering the theoretical Si/Al ratio of kaolinite $\sim$ 1. The high Si/Al ratio of the other raw clays than SS indicates the presence of 2:1 clay minerals and/or more free silica (e.g. quartz). The high amount of $\mathrm{K}_{2} \mathrm{O}$ suggests the presence of illite. Low amount of $\mathrm{CaO}$ reflects the non-calcareous nature of the clays.

The X-ray diffraction patterns of the raw clays (Figure 1 ) and the mineralogical composition (Table 2) show that SS comprises mainly of kaolinite (75\%), which explains the low $\mathrm{Si} / \mathrm{Al}$ ratio compared to the other clays. A weak reflection peak of illite was also observed as well as of quartz. The XRD pattern of BS shows that it is composed of kaolinite (34\%), illite (35\%) and a large amount of quartz (30\%). Unlike SS and BS clays, MS and WS have a low amount of kaolinite. A wellcrystallized pyrophyllite (43.6\%) and illite (30.4\%) were found to be the main clay minerals present in MS clay. The 001 reflections of $14.9 \AA$, which is typical for dioctahedral smectite, was observed in the XRD pattern of WS. The results reveal that WS is composed of illite/smectite (27.2\%) and nontronite $\left(\mathrm{Fe}^{3+}\right.$-rich dioctahedral smectite, 37\%), together with $20 \%$ of illite. The presence of nontronite and goethite in the WS explains $17.5 \%$ of $\mathrm{Fe}_{2} \mathrm{O}_{3}$ present in the samples (Table 1).

The particle size distribution and specific surface area of the raw clays (Table 2 ) are strongly affected by the mineralogical composition of the clays. The BET surface area of BS is higher than SS due to the presence of a larger amount of illite in BS, which can be explained by a larger specific surface than kaolinite [21]. MS represents the lowest BET surface due to the presence of $43.6 \%$ of pyrophyllite, which is characterized by a smaller surface area [22]. The results also show that WS has a larger particle size fraction than the other clay samples, which is explained by its sandy nature. 
Table 1. Bulk chemical composition (mass \%) and $\mathrm{Si} / \mathrm{Al}$ molar ratio of clay raw materials, the $\mathrm{Si} / \mathrm{Al}$ ratios are calculated based on the $\mathrm{SiO}_{2} / \mathrm{Al}_{2} \mathrm{O}_{3}$ of the raw clays. LOI: Loss on ignition at $1050^{\circ} \mathrm{C}$

\begin{tabular}{cccccccccccc}
\hline & $\mathrm{Al}_{2} \mathrm{O}_{3}$ & $\mathrm{SiO}_{2}$ & $\mathrm{CaO}$ & $\mathrm{Fe}_{2} \mathrm{O}_{3}$ & $\mathrm{~K}_{2} \mathrm{O}$ & $\mathrm{MgO}$ & $\mathrm{Na}_{2} \mathrm{O}$ & $\mathrm{TiO}_{2}$ & $\mathrm{P}_{2} \mathrm{O}_{5}$ & LOI* & Si/Al \\
\hline SS & 33.89 & 49.30 & 0.09 & 0.97 & 1.67 & 0.25 & 0.16 & 0.87 & 0.07 & 12.81 & 1.2 \\
$\mathrm{BS}$ & 23.53 & 59.89 & 0.22 & 1.22 & 1.99 & 0.34 & 0.20 & 1.34 & 0.06 & 8.30 & 2.2 \\
$\mathrm{MS}$ & 27.06 & 52.37 & 0.68 & 2.87 & 2.88 & 0.61 & 0.80 & 1.12 & 0.13 & 9.52 & 1.6 \\
WS & 10.71 & 43.42 & 1.85 & 17.47 & 0.28 & 5.78 & 0.03 & 1.59 & 0.25 & 18.63 & 3.4 \\
\hline
\end{tabular}

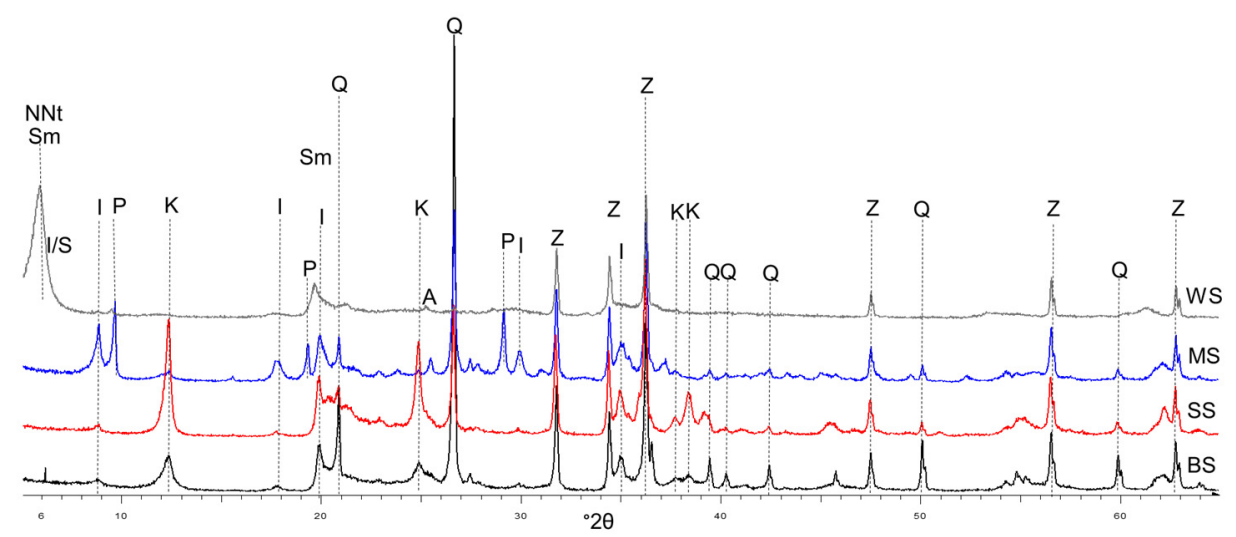

Figure 1. XRD patterns of raw and calcined clays. Kaol: kaolinite, I: illite, P: pyrophyllite, NNt: nontronite, Sm: smectite, I/S: Illite/smectite, Z: zincite, Q: quartz, A: anatase.

Table 2. Quantitative minerals' phase compositions and physical properties of the raw clays

\begin{tabular}{|c|c|c|c|c|}
\hline \multirow{2}{*}{$\begin{array}{l}\text { Mineralogical } \\
\text { composition }\end{array}$} & SS & BS & MS & WS \\
\hline & \multicolumn{4}{|c|}{ Mass (\%) } \\
\hline \multicolumn{5}{|l|}{ Clay minerals } \\
\hline Kaolinite & 75 & 34 & 13 & 3 \\
\hline Illite & 16 & 35 & 30.4 & 20 \\
\hline Ca-smectite & - & - & - & 3 \\
\hline Pyrophyllite & - & - & 43.6 & - \\
\hline Illite/Smectite & - & - & - & 27.2 \\
\hline Nontronite & - & - & - & 37 \\
\hline \multicolumn{5}{|l|}{ Non-clay minerals } \\
\hline Quartz & 8 & 30 & 13 & 0.5 \\
\hline Anatase & 1 & 1 & 1 & 1 \\
\hline Goethite & - & - & - & 6.6 \\
\hline Talc & - & - & - & 1.1 \\
\hline Calcite & - & - & - & 0.5 \\
\hline \multicolumn{5}{|l|}{ Physical properties } \\
\hline $\mathrm{S}_{\mathrm{BET}}\left(\mathrm{m}^{2} / \mathrm{g}\right)$ & 22.9 & 27.6 & 14.6 & 2.7 \\
\hline $\mathrm{d}_{10}(\mu \mathrm{m})$ & 0.4 & 0.9 & 2.8 & 49.7 \\
\hline $\mathrm{d}_{50}(\mu \mathrm{m})$ & 3.9 & 7.1 & 25.5 & 327.8 \\
\hline $\mathrm{d}_{90}(\mu \mathrm{m})$ & 50.4 & 39.8 & 160.7 & \\
\hline
\end{tabular}

\subsection{Thermal treatment of clays}

TGA and the mass losses after calcination were calculated on calcined clays at different temperatures and different holding times. The results (not presented) show that clays were dehydroxylated at temperatures $\geq 800{ }^{\circ} \mathrm{C}$ and for a holding time $\geq 10$ minutes, and there was no a significant difference between clays that were calcined at 10 and 60 minutes. To assess the complete dehydroxylation of clays, XRD was performed for the calcined clays at 800 and $900{ }^{\circ} \mathrm{C}$ for 10 minutes. Figure 2 shows that there are structural transformations after the calcination of clays. The results reveal a complete disappearance of the peak of kaolinite present in SS and BS (Figure $2 \mathrm{a} \& \mathrm{~b}$ ), which is an indication of a complete dehydroxylation of kaolinite. The illite structure tends to persist after calcination at high temperatures. MS clay consists of relatively high amounts of pyrophyllite, the peak intensity of the pyrophyllite slightly reduces with a slight shift in the 001 reflections. Moreover, the crystallinity of the dehydroxylated phase is not greatly different compared to the ideal mineral structure [23]. The calcination of WS at 900 ${ }^{\circ} \mathrm{C}$ shows more structural transformation than at $800{ }^{\circ} \mathrm{C}$ due to the domination of 2:1 dioctahedral smectite in the clay structure. The XRD pattern indicates that the dehydroxylation does not result in a complete collapse of the smectite structure. It was clearly observed in all the XRD patterns that the sharp peaks of quartz do not alter after calcination. The effect on the background in the XRD patterns after calcination was more pronounced in the samples that contain high amount of kaolinite and montmorillonite than in the samples that contain illite or pyrophyllite, which tend to not alter after calcination. 

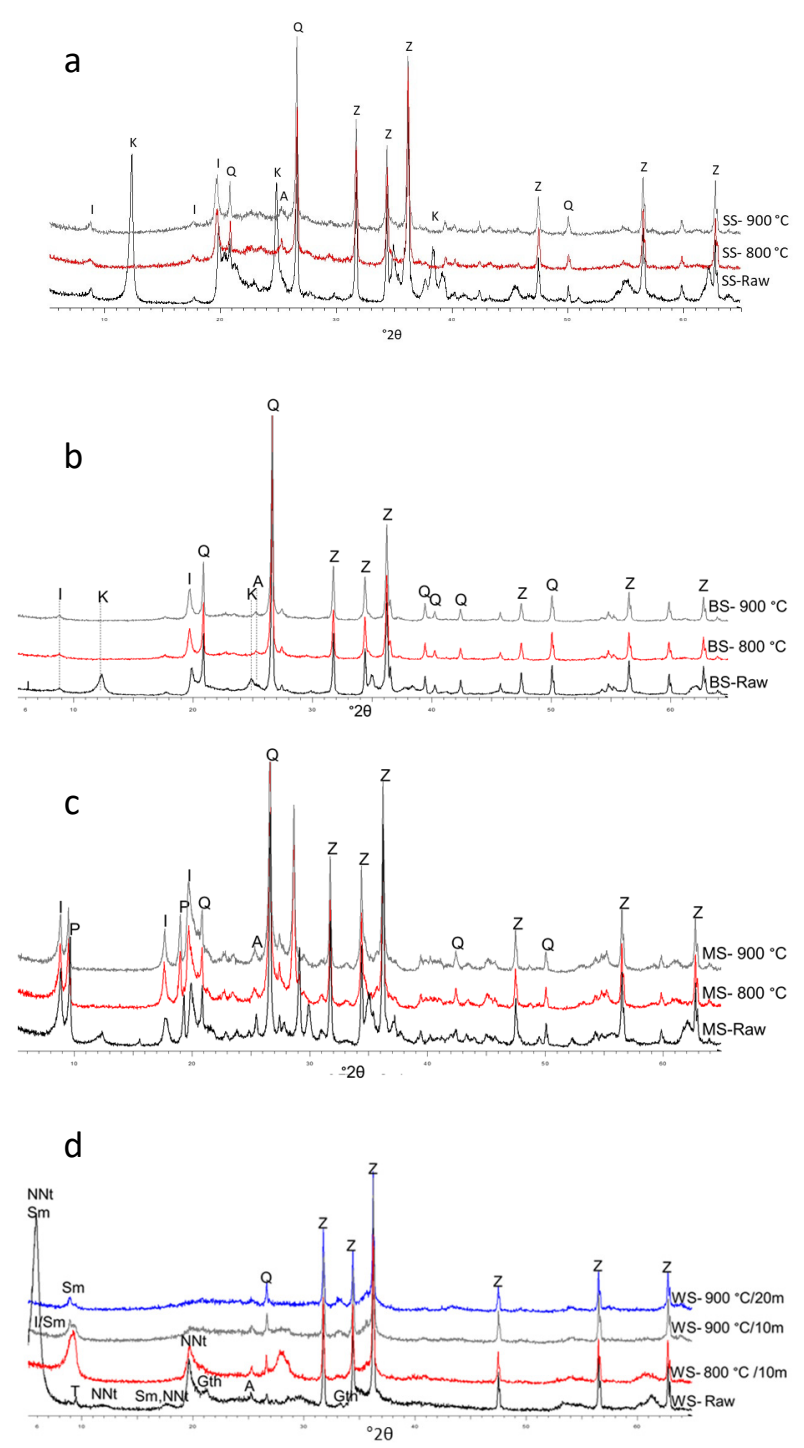

Figure 2. XRD patterns of raw and calcined clays at 800 and $900{ }^{\circ} \mathrm{C}$ for 10 minutes. Kaol: kaolinite, I: illite, P: pyrophyllite, Sm: smectite, NNt: nontronite, Gth: Goethite, T: talc, A:Anatase, Z: zincite, Q: quartz. (a: SS, b: BS, c: MS, d: WS).

\subsection{Reactivity of the calcined clays in alkaline media}

The dissolution behavior of the calcined clays as a function of temperature and holding time is displayed in Table 3. The dissolution behavior of clays can be congruent when the dissolution ratio of Si:Al in the alkaline solution is similar to the Si:Al ratio in the solid raw materials; or incongruent [24,25]. The results show that in SS, BS, and MS, the Si and Al released to the solution are of similar magnitude after 24 hours of dissolution. The concentration of Si in WS is higher than the concentration of Al due to the domination of 2:1 clay minerals and the high Si/Al ratio. It is worth mentioning that the amount of dissolved Si and Al in SS, BS and MS varies as the amount of kaolinite in each clay varies. SS shows the highest amount of dissolved $\mathrm{Si}$ and $\mathrm{Al}$ due to the presence of high amounts of kaolinite (75\%). This is followed by BS, which contains $35 \%$ kaolinite. MS composes mainly of pyrophyllite and illite, shows the lowest dissolution rate of Si and Al. The pyrophyllite in MS structure tends to persist its crystallinity and inaccessibility of the Al-O sheet to the alkaline reaction solution [24], which also can be seen in the XRD results. The amount of dissolved Si and Al from MS is due to the presence of $13 \%$ of kaolinite in the clay structure. From the dissolution experiments of SS, BS and MS, it can be concluded that the dissolution of kaolinite can be considered as congruent but the overall dissolution reaction is nonstoichiometric [24].

Clays calcined at 700 and $850^{\circ} \mathrm{C}$ for 10 minutes show a slightly lower extent of dissolution than those calcined at 800 and $900^{\circ} \mathrm{C}$. There is no considerable difference between the concentration of $\mathrm{Si}$ and $\mathrm{Al}$ in the clays calcined at 800 and $900{ }^{\circ} \mathrm{C}$, while the only considerable difference is observed in WS clay. The results show that calcination of WS at $900{ }^{\circ} \mathrm{C}$ results in a higher amount of amorphous aluminosilicate phase than at $800^{\circ} \mathrm{C}$. These results are in agreement with the XRD results (Figure $3 d$ ) of calcined WS clay at 800 and $900^{\circ} \mathrm{C}$.

To finally assess the calcination temperature and holding time of these clays, the cumulative heat released from the reaction of the calcined clays with $8 \mathrm{M} \mathrm{NaOH}$ was measured to study the clay reactivity at different calcination temperatures and times (Figure 3). The results revealed that the maximum heat released in case of SS, BS and MS was when the clays were calcined at $800^{\circ} \mathrm{C}$ for 10 minutes. The calorimetry and XRD results of WS show that the optimum calcination temperature that ensures the highest reactivity and highest degree of dehydroxylation was when the sample was calcined at $900^{\circ} \mathrm{C}$ for 20 minutes.

Table 3. Dissolution concentrations of $\mathrm{Al}$ and $\mathrm{Si}(\mathrm{mol} / \mathrm{kg})$ after 24 hours of dissolution in $6 \mathrm{M} \mathrm{NaOH}$

\begin{tabular}{lllllllll}
\hline \multirow{2}{*}{$\begin{array}{l}\text { Temperature/ } \\
\text { holding time }\end{array}$} & SS & \multicolumn{3}{c}{$\mathrm{BS}$} & \multicolumn{3}{c}{$\mathrm{MS}$} & \multicolumn{3}{c}{ WS } \\
\cline { 2 - 9 } & $\mathrm{Al}$ & $\mathrm{Si}$ & $\mathrm{Al}$ & $\mathrm{Si}$ & $\mathrm{Al}$ & $\mathrm{Si}$ & $\mathrm{Al}$ & $\mathrm{Si}$ \\
\hline $700^{\circ} \mathrm{C} / 10 \mathrm{~m}$ & 5.37 & 5.45 & 2.82 & 3.05 & 0.88 & 0.91 & 0.69 & 2.13 \\
$800^{\circ} \mathrm{C} / 10 \mathrm{~m}$ & 5.74 & 5.82 & 3.13 & 3.31 & 0.92 & 1.08 & 0.88 & 2.79 \\
$850^{\circ} \mathrm{C} / 10 \mathrm{~m}$ & 4.59 & 4.70 & 3.03 & 3.24 & 0.98 & 1.28 & 1.00 & 3.03 \\
$900^{\circ} \mathrm{C} / 10 \mathrm{~m}$ & 5.94 & 6.33 & 3.09 & 3.33 & 0.98 & 1.31 & 1.06 & 4.19 \\
\hline
\end{tabular}



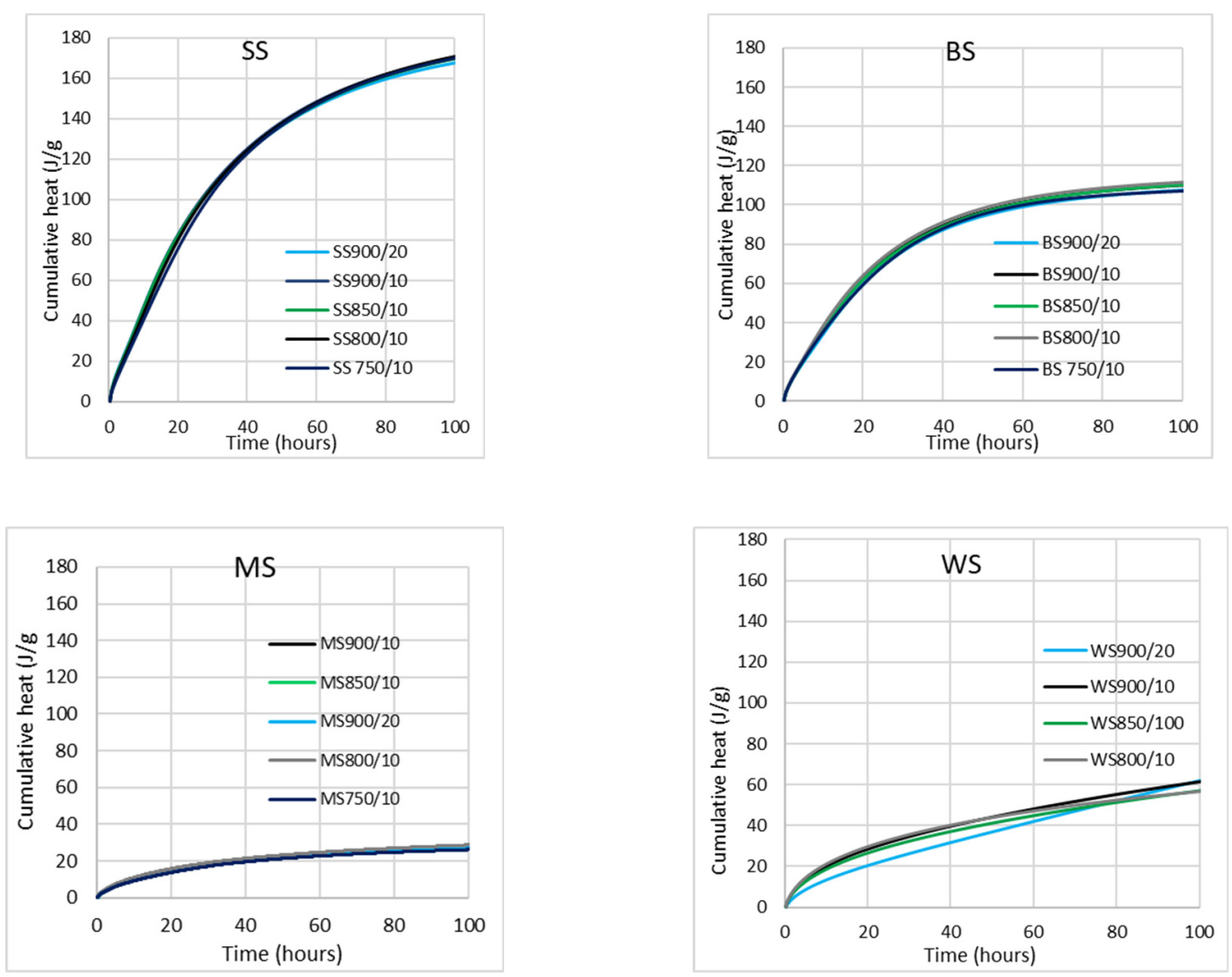

Figure 3. The cumulative heat of the calcined clays activated by $8 \mathrm{M} \mathrm{NaOH}$ measured at $20^{\circ} \mathrm{C}$ within 5 days. As an example: SS $900 / 20$, stands for sample SS, calcined at $900{ }^{\circ} \mathrm{C}$ for 20 minutes.

\subsection{Effect of the alkaline activator on the geopolymerization reaction}

The selected calcined clay samples were mixed with $\mathrm{NaOH}$, and $\mathrm{NaOH} / \mathrm{Na}_{2} \mathrm{SiO}_{3}$, the solution/binder ratio kept the same to enable the comparison. Table 4 shows the mix proportions and the corresponding molar ratios of the geopolymers.

Table 4. Mix design of calcined clay-based geopolymers and the composition of the corresponding geopolymerization systems, defined as molar ratios

\begin{tabular}{|c|c|c|c|c|}
\hline \multirow{2}{*}{ Mix no } & \multicolumn{3}{|c|}{ Mix Proportions (wt\%) } & \multirow{2}{*}{$\begin{array}{l}\begin{array}{l}\text { Oxides } \\
\text { molar } \\
\text { ratios }\end{array} \\
\mathrm{Na}_{2} \mathrm{O} / \mathrm{H}_{2} \mathrm{O}\end{array}$} \\
\hline & $\mathrm{SiO}_{2} / \mathrm{Al}_{2} \mathrm{O}_{3}$ & $\mathrm{SiO}_{2} / \mathrm{Na}_{2} \mathrm{O}$ & $\mathrm{Na}_{2} \mathrm{O} / \mathrm{Al}_{2} \mathrm{O}_{3}$ & \\
\hline CSS 1 & 1.2 & - & 1.21 & 0.11 \\
\hline CSS 2 & 1.2 & 1.45 & 0.72 & 0.06 \\
\hline CBS 1 & 2.2 & - & 1.74 & 0.11 \\
\hline CBS 2 & 2.2 & 1.45 & 1.04 & 0.06 \\
\hline CMS 1 & 1.6 & - & 1.51 & 0.11 \\
\hline CMS2 & 1.6 & 1.45 & 0.9 & 0.06 \\
\hline CWS 1 & 3.4 & - & 3.82 & 0.11 \\
\hline CWS 2 & 3.4 & 1.45 & 2.28 & 0.06 \\
\hline
\end{tabular}

*CSS: is calcined SS as an example
The curves of the cumulative heat released from the geopolymerization reaction have relatively the same trend regardless of the type of calcined clays (Figure 4). During the first 24 hours of the geopolymerization reaction, the total amount of heat released in the $\mathrm{NaOH}$ system is nearly the same as in the $\mathrm{NaOH} / \mathrm{Na}_{2} \mathrm{SiO}_{3}$ system, even though the geopolymerization reaction mechanism is different. The geopolymerization reaction is a chemical reaction that can be measured by the amount of heat absorbed or released during the reaction (endothermic/exothermic reactions) [26,27]. In the first 24 hours, the amount of the heat released from the endothermic/exothermic reactions accompanied the dissolution/hydrolysis stage are higher in the $\mathrm{NaOH}$ system than in the $\mathrm{NaOH} / \mathrm{Na}_{2} \mathrm{SiO}_{3}$ system. In contrary, the exothermic reaction of the geopolymerization reaction releases more heat in the $\mathrm{NaOH} / \mathrm{Na}_{2} \mathrm{SiO}_{3}$ system than in the $\mathrm{NaOH}$ system [27]. This explains that in the first 24 hours of the reaction, the total amount of heat released is nearly the same. Activation of the calcined clays with $\mathrm{NaOH} / \mathrm{Na}_{2} \mathrm{SiO}_{3}$ provides additional soluble silicates to the reaction, which retard the dissolution and geopolymerization reaction $[27,28]$. A possible reason for this is that the additional soluble silicates possibly form silicate-rich layers on the surface of unreacted calcined clays and therefore retard the dissolution and geopolymerization reaction. This can explain the difference in the amount of heat released in the two systems after 24 hours. 


\section{The calorimetry curves}

The heat released during the reaction of all the calcined clays with $\mathrm{NaOH}$ and $\mathrm{NaOH} / \mathrm{Na}_{2} \mathrm{SiO}_{3}$ were taken at $\sim 7$ days of reaction as the reaction seems to slow down at this age. The calorimetry curves show that the cumulative heat release reaches a plateau sooner for the calcined clays that were mixed with $\mathrm{NaOH} / \mathrm{Na}_{2} \mathrm{SiO}_{3}$ than that were mixed with only $\mathrm{NaOH}$. The cumulative heat release of SS sample, which composed of $75 \%$ kaolinite, is $\sim 230 \mathrm{~J} / \mathrm{g}$. This amount of cumulative heat counts as double as the amount of heat released by BS sample which composed of $35 \%$ kaolinite. The rest of the samples follows the same trend, which is in a good agreement with the results of the dissolution tests. The cumulative heat release of the calcined clays, which indicates the reactivity of the calcined clays towards the alkaline activation, is strongly depends on the mineralogical composition of each sample, or more specifically on the kaolinite content.

\section{Conclusion}

The geopolymerization process is known to be strongly influenced by the degree of dehydroxylation of the clay minerals present. The optimum calcination temperature, which is required to completely dehydroxylate the clay structure, is mainly affected by the mineralogical composition of the raw clays. The dehydroxylation of clays does not necessarily cause the transition from crystalline to an amorphous structure. The dehydroxylation of kaolinite seems to convert its crystalline structure into an amorphous one, thus, the reactivity towards alkali activation increases. In contrast, illite and pyrophyllite seem to retain their basic layered structure after dehydroxylation.

Calcination of clays was completed after 10 minutes of holding time show that there is no significant difference between clays calcined at 10 and 60 minutes. The total cumulative heat released from the reaction of SS and BS, which was calcined for 20 minutes, is less than or equal to the one calcined only for 10 minutes. The holding time does not have a clear effect on increasing or decreasing the reactivity of MS. In the case of WS, holding time of 20 minutes slightly increases the reactivity of the calcined clays compared with the clays calcined only for 10 minutes.

The reactivity of calcined natural clays in alkaline media is influenced by the type of alkali activators as well as by its mineralogical composition. The dissolution and calorimetry results show that kaolinite-rich clays (SS) present more reactivity towards alkali activation than clays dominated by smectite or illite. The results also show a very low reactivity of the MS clay, which is composed mainly of pyrophyllite. The reactivity of calcined clays using $\mathrm{NaOH}$ is higher than with $\mathrm{Na}_{2} \mathrm{SiO}_{3}$.
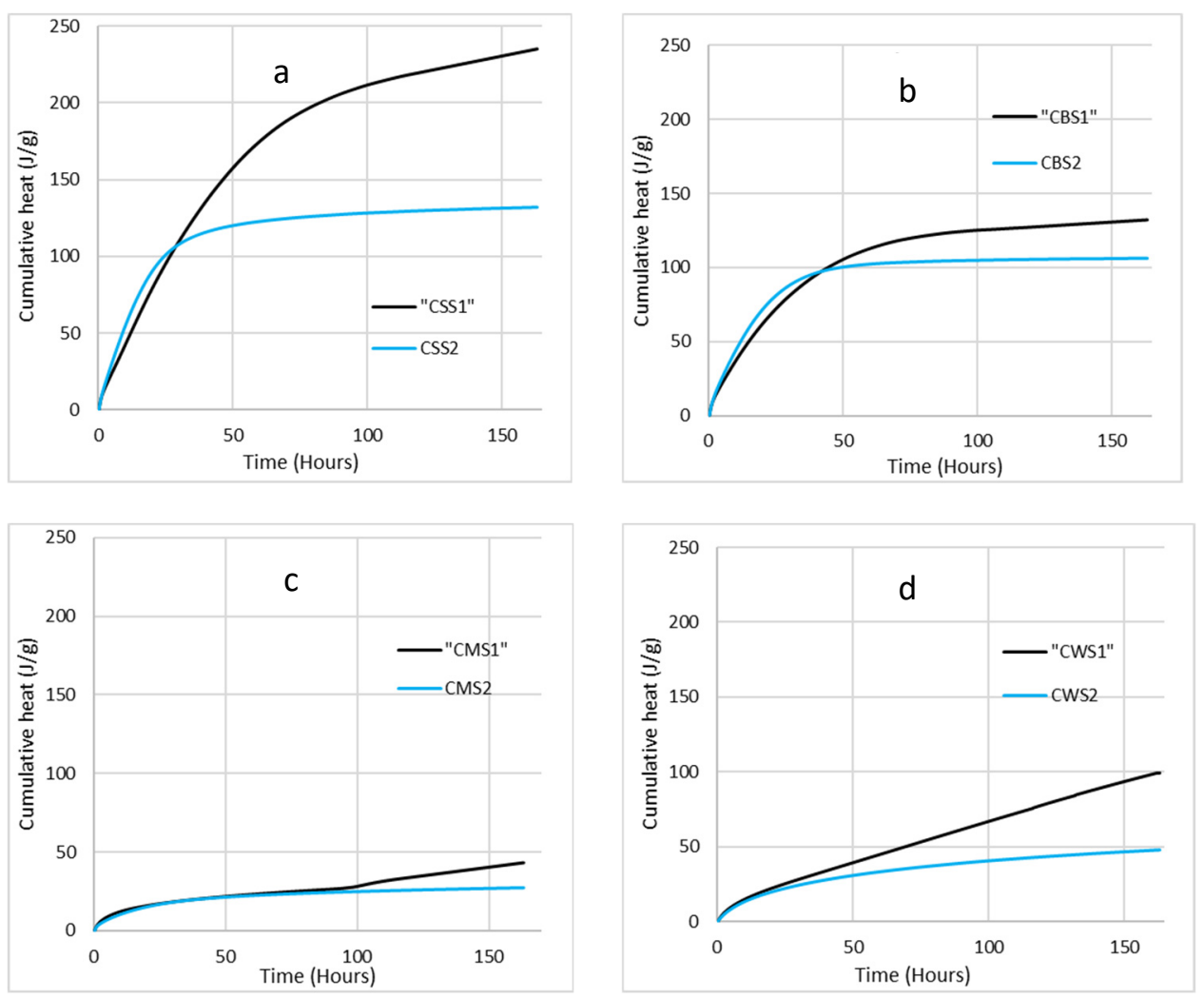

Figure 4. The cumulative heat of the calcined clays activated by $\mathrm{NaOH}$ and $\mathrm{NaOH} / \mathrm{Na}_{2} \mathrm{SiO}_{3}$, measured at $20^{\circ} \mathrm{C}$ within 7 days. (a: $\mathrm{CSS}$, b: $\mathrm{CBS}$, c: CMS, d: CWS). 


\section{References}

[1] Z. H. Zhang, H. J. Zhu, C. H. Zhou, H. Wang, Geopolymer from kaolin in China: An overview. Appl Clay Sci 2016 (119): 31-41. https://doi.org/10.1016/j.clay.2015.04.023

[2] Y. M. Liew, C. Y. Heah, A. B. Mohd Mustafa, H. Kamarudin, Structure and properties of clay-based geopolymer cements: A review. Progress in Material Science 2016(83): 595-629. https://doi.org/10.1016/i.pmatsci.2016.08.002

[3] J. L. Provis, S. L. Yong, P. Duxson, Nanostructure/microstructure of metakaolin geopolymers. Boca Raton Boston: Woohead Publishing Limited, 2009, pp. 72-88. https://doi.org/10.1533/9781845696382.1.72

[4] K.L. Scrivener, V.M. John, E.M. Gartner, Eco-efficient cements: potential, economically viable solutions for a low-CO2, cement-based materials industry. Cem Concr Res 2018(114):2-26. https://doi.org/10.1016/i.cemconres.2018.03.015

[5] C. He, B. Osbæck, E. Makovicky, Pozzolanic reactions of six principal clay minerals activation, reactivity assessments and technological effects. Cem Concr Res 1995(25): 1691-1702. https://doi.org/10.1016/0008-8846(95)00165-4

[6] C. He, E. Makovicky, B. Osbæck, Thermal stability and pozzolanic activity of calcined illite. Appl Clay Sci 1995(9): 337-354. https://doi.org/10.1016/0169-1317(94)00033-M

[7] C. He, E. Makovicky, B. Osbæck, Thermal treatment and pozzolanic activity of Na- and Ca-montmorillonite. Appl Clay Sci 1996(10): 351368. https://doi.org/10.1016/0169-1317(95)00037-2

[8] C. He, E. Makovicky, B. Osbæck, Thermal treatment and pozzolanic activity of sepiolite. Appl Clay Sci 1996(10) 337-349. https://doi.org/10.1016/0169-1317(95)00035-6

[9] C. He, E. Makovicky, B. Osbæck. Thermal stability and pozzolanic activity of raw and calcined mixed-layer mica/smectite. Appl Clay Sci 2000(17): 141-161. https://doi.org/10.1016/S0169-1317(00)00011-9

[10] S. Hollanders, R. Adriaens, J. Skibsted, Ö. Cizer, J. Elsen, Pozzolanic reactivity of pure calcined clays. Appl Clay Sci 2016(132-133): 552560. https://doi.org/10.1016/j.clay.2016.08.003

[11] S. Hollanders, Mineralogical study of the pozzolanic properties of calcined clays. April, 2017.

[12] B. B. Sabir, S. Wild, J. Bai. Metakaolin and calcined clays as pozzolans for concrete: a review. Cem Concr Compos 2001(23): 441-54. https://doi.org/10.1016/S0958-9465(00)00092-5

[13] R. Fernandez, F. Martirena, K. L. Scrivener, The origin of the pozzolanic activity of calcined clay minerals: A comparison between kaolinite, illite and montmorillonite. Cem Concr Res 2011(41): 113122. https://doi.org/10.1016/i.cemconres.2010.09.013

[14] A. Tironi, M. a. Trezza, A. N. Scian, E. F. Irassar, Assessment of pozzolanic activity of different calcined clays. Cem Concr Compos 2013(37): 319-327. https://doi.org/10.1016/j.cemconcomp.2013.01.002

[15] A. Marsh, A. Heath, P. Patureau, M. Evernden, P. Walker, Alkali activation behaviour of un-calcined montmorillonite and illite clay minerals. Appl Clay Sci 2018(166): 250-261. https://doi.org/10.1016/i.clay.2018.09.011

[16] A. Marsh, A. Heath, P. Patureau, M. Evernden, P. Walker, Applied clay science phase formation behaviour in alkali activation of clay mixtures. Appl Clay Sci 2018(175): 10-21. https://doi.org/10.1016/i.clay.2019.03.037

[17] T. Seiffarth, M. Hohmann, K. Posern, C. Kaps, Effect of thermal pretreatment conditions of common clays on the performance of claybased geopolymeric binders. Appl Clay Sci 2013(73): 35-41. https://doi.org/10.1016/i.clay.2012.09.010

[18] C. Belviso, F. Cavalcante, G. Niceforo, A. Lettino, Sodalite, faujasite and a-type zeolite from $2: 1$ dioctahedral and $2: 1: 1$ trioctahedral clay minerals. A singular review of synthesis methods through laboratory trials at a low incubation temperature. Powder Technol 2017(320): 483-497. https://doi.org/10.1016/j.powtec.2017.07.039

[19] G. Habert, N. Choupay, G. Escadeillas, D. Guillaume, J. M. Montel, Clay content of argillites: Influence on cement based mortars. Appl Clay Sci 2009(43): 322-330. https://doi.org/10.1016/j.clay.2008.09.009

[20] C. Manoharan, P. Sutharsan, S. Dhanapandian, R. Venkatachalapathy, Characteristics of some clay materials from Tamilnadu, India, and their possible ceramic uses. Cerâmica 2012(58): 412-418. https://doi.org/10.1590/S0366-69132012000300021

[21] A. Gharzouni, B. Samet, S. Baklouti, E. Joussein, S. Rossignol, Addition of low reactive clay into metakaolin-based geopolymer formulation:
Synthesis, existence domains and properties. Powder Technol 2016(288): 212-220.

https://doi.org/10.1016/j.powtec.2015.11.012

[22] J. L. Preze-Rodriquez, L. Madrid Sanchez Del Villar, PJ. Sanchez-Soto, Effects of dry grinding on pyrophyllite. Clay Miner 1988(23): 399-410. https://doi.org/10.1180/claymin.1988.023.4.07

[23] K. J. D. Mackenzie, S. Komphanchai ,R. Vagana, Formation of inorganic polymers (geopolymers) from 2: 1 layer lattice aluminosilicates. J Eur Ceram Soc 2008(28): 177-181. https://doi.org/10.1016/j.jeurceramsoc.2007.06.004

[24] R. October, Mechanism of kaolinite dissolution at room temperature and pressure Part II : Kinetic study. Geochim Cosmochim Ac 1999(63): 3261-3275. https://doi.org/10.1016/S0016-7037(99)00249-5

[25] I. Aldabsheh, H. Khoury, J. Wastiels, H. Rahier, Applied clay science dissolution behavior of Jordanian clay-rich materials in alkaline solutions for alkali activation purpose. Part I. Appl Clay Sci 2015(115): 238-247. https://doi.org/10.1016/j.clay.2015.08.004

[26] F. Pacheco-Torgal, J. Castro-Gomes, S. Jalali, Alkali-activated binders: A review. Part 1. Historical background, terminology, reaction mechanisms and hydration products. Constr Build Mater 2008(22): 1305-1314. https://doi.org/10.1016/j.conbuildmat.2007.10.015

[27] M. B. Ogundiran, S. Kumar, Synthesis and characterisation of geopolymer from Nigerian Clay. Appl Clay Sci 2015(108): 173-181. https://doi.org/10.1016/i.clay.2015.02.022

[28] J. L. Provis, J. S. J. van Deventer. Geopolymerisation kinetics. 1. In situ energy-dispersive X-ray diffractometry. Chem Eng Sci 2007(62): 23092317. https://doi.org/10.1016/j.ces.2007.01.027 